ernmental Studies, University of California, 1992).

Byran was well known in Southern California for his commehts on African-American and urban political issues. At one time or another, he had been interviewed and quoted in every publication from Time and Newsweek to the Los Angeles Times, local television, and cable TV. In February, 1988, the Beta Pi Sigma Sorority of Los Angeles awarded him their "Outstanding Black Achiever" award in recognition of his contributions to the Los Angeles black community.

As a member of the consulting firm Urban Research Associates, Byran became an important resource for local and national political and advocacy organizations. He was instrumental in the Garza v. Los Angeles case as an expert witness on behalf of the NAACP Legal and Defense Education Fund. In 1992, he helped a number of local candidates and city council members with reapportionment problems using Census data and a microcomputer based mapping program on which he had become quite an expert. He had recently helped the Simon Wiesenthal Center in Los Angeles on an interactive exhibit that relates to the Los Angeles riots. In the month before he died, October, 1992, the Los Angeles Times, in an article on political commentators in California, cited him as an "upcoming" California "political pundit."

Within the university, Byran taught everything from a freshman large lecture on American/California politics to a graduate seminar on program evaluation. He had built the urban politics area over the years into an area of strong demand. He demanded much of his students, and a number have said that as a result of his high expectations, they had learned material, particularly in the area of quantitative methods and evaluation methodology, that they had never expected to understand.

Byran's vast knowledge of political science, public policy, public administration, and California politics, his willingness to help students, faculty and friends and his general love of life made him one of the most well known faculty at Cal State LA and an enthusiastic member of the political science community in Southern
California. His friends and family will miss him dearly. His impact on us will be long remembered.

Contributions may be made to the "Byran O. Jackson Memorial Scholarship" by sending a check payable to "CSLA Foundation" to the Department of Political Science, California State University, Los Angeles, CA 90032-8226.

J. Theodore Anagnoson

California State University, Los Angeles

Melvin Oliver

University of California, Los Angeles

Michael B. Preston

University of Southern California

\section{Orma Linford}

A constitution is not a thing in name only, but in fact. ... The constitution of a country is not the act of the government, but of the people constituting a government.

Thomas Paine, in the window of Kedzie 219C

Orma Linford, teacher, adviser, and friend to a generation of Kansas State University students and passionate civil libertarian since the turbulent 1960 s, died January 28 from injuries suffered in a fall at her home in Manhattan, Kansas.

A Utah native, Professor Linford joined the KSU department of political science in 1966 soon after earning her doctorate at the University of Wisconsin. Her case-based, Socratic teaching influenced a host of lawyers now practicing nationwide throughout United States jurisprudence.

Students remember a strikingly beautiful, stunningly dressed expositor tall at the lectern or sailing the aisles of Kedzie Hall classrooms. At once, she was relentlessly intolerant of cant and evasion, and ever tolerant, compassionate, and optimistic to a fault with each individual person.

As Vietnam-era protests swept American campuses, Professor Linford assisted the defense of scores of alleged victims of civil rights violations and race and gender discrimination. She was a long-time member of the Kansas State University Faculty Senate and author of many of the University's due process guideines.
Professor Linford helped found opportunities for laypeople and nontraditional students in the University for Man, and the department's Current Issues course.

Professor Linford's humanity shone through a memorial service for her. A former student relived "The Course," her packed offerings in constitutional law and defendants' rights. Colleagues recalled her fun, her gender-neutral dignity before fashionable feminism, and her serenity, her ire, and her grace under pressure of inane conformity or tyranny of petty authority. A friend of thirty years imagined that if there were a waiting line at heaven's gates, Orma Linford would find kinship with two others who recently died, Thurgood Marshall and Audrey Hepburn. Orma would add Dizzy Gillespie to the company, and from up front in the line, Miles Davis. A former student said Orma Linford's death retired the word "splendid" from her vocabulary.

Professor Linford was born April 10, 1935 in Cedar City, Utah, to the late H. B. (Tuff) Linford and Lillian O. Linford. She was graduated Phi Beta Kappa from Utah State University, and taught briefly at Beloit College in Wisconsin. She is survived by her brother, H. G. Linford, her sister, Lynda Linford, her niece, Jill Linford, all of Salt Lake City; her nephew, Scott Linford, a third-year KSU Veterinary Medicine student, and his wife, Trisa, and her grandnephew, Tate Howard Linford.

Her family and friends established an Orma Linford pre-law scholarship and assistance fund in her memory, and efforts are underway to perpetuate her excellence and her memory in a professorship in constitutional law. Inquiries and contributions can be directed to the Department of Political Science, or to the KSU Foundation, Manhattan, KS 66506.

Those human rights include the right to put one's face in clear, pure water, to discover the wonders of sphagnum moss, to hear the song of whippoorwills at dawn in a forest where the wilderness bowl is unbroken.

Justice William O. Douglas

Alden Williams

Kansas State University 